\title{
Framing the Refugee
}

\section{Phil Cole}

University of the West of England, Bristol, Phil.Cole@uwe.ac.uk

DOI: http://dx.doi.org/10.5324/eip.v14i2.3489

(cc) BY

This is an open access article distributed under the terms of the Creative Commons Attribution 4.0 International License, which permits unrestricted use, distribution, and reproduction in any medium, provided the original author and source are credited.

'Framing the Refugee' looks at the power of representation of liberal political theory with regard to refugees. In the author's view, legal and political arbitrariness lies in the representing of refugees as lacking agency. His key point is that liberalism fails to conceive of refugees as politically capable actors, and he is thus complicit in the arbitrary neutralisation of their emancipatory potential and participatory powers. This paper emphasises the moral justifiability of that state of affairs by seeking some answers to the question of why liberal political theory construes a concept of the refugee that does not contain any element of political agency. Most obviously, the author acknowledges that refugees perform a significant social role in contemporary societies and are hence active members in them. Nonetheless, they remain neglected in their political role by most political theory. What does it mean to have political agency for the author? It means to have the power of self-representation, that is, of being allowed and even enabled by a given legal system to bring about change in the political order, or at least to participate in that change. But the author also calls attention to the role of 'theory' in addressing this downside of the contemporary liberal democratic order. Theory becomes even more crucial at times of urgency, that is, when theorists have a moral responsibility to deepen their philosophical imagination, as Hannah Arendt so forcefully noted. The theoretical task of 'reframing' the refugee entails reconfiguring political philosophy and its traditional categories of sovereignty, citizenship and nationality. The liberal inability to accommodate the political agency of many members of the political community especially of non-nationals - is a sign of the historical contingency of the current rules of political membership. This inability makes evident the imperative of rethinking politics in ways that avoid the arbitrariness of treatment and aim instead at equality and justice. If political leaders can re-write the rules of membership to suit their own ideological agendas, the same demand should be addressed by - indeed demanded from - political and legal theorists. However, this is not as easy as it seems, according to the author. In his view, political theory is confronted with fundamental challenges, the most obvious one being that 'theory' is usually unequipped to defeat its own 'topology'. Note that in saying this the author is raising a more pressing concern about arbitrary law-making: it may be that arbitrariness - especially the arbitrary treatment of aliens by the sovereign state and by liberal democracies in particular is inscribed in the very DNA of liberalism. No matter how odd this may seem, the author advances the view that ideas, however creative of a new order, or transformative of a given status quo, never appear in "free form", and are instead 
deeply rooted in a structure that constrains our imagination. The challenge is thus to develop a meta-theory that reconceptualises the very way liberal political theory frames marginalised sectors of society - such as the "poor" - as a product of an international economic order that robs those sectors of their agency as the very condition of its internal functioning. We must therefore question how the very idea of the refugee is produced, because it symbolises the construction of an inside and an outside that is complicit with the arbitrary play of legal statuses involved in migration policy. The author's main point regarding this is that certain groups are sidelined by economic, political and social systems because they are already excluded from theoretical systems to start with.

Keywords: refugees, agency, political theory, migration

\section{Introduction}

My aim in this paper is to explore how the idea of the refugee is produced - and specifically how it is produced in liberal political theory - as opposed to how people actually become refugees. I argue that this body of theory constructs the concept of refugees in ways that constrain their political agency, or indeed as having no agency at all. They are seen as helpless figures who need assistance from the international community in order to be reinserted into a national political order - either through voluntary repatriation, integration into the host country, or re-settlement in a third country. There is a body of literature arguing that refugees do exercise political agency on the ground, in getting themselves out of danger in the first place and reaching a place of safety, and subsequently in finding their own solutions to their displacement (see King 2016 for a discussion of this approach, which sees escape or flight as an assertion of agency; also see Lenard 2020); and that even in refugee camps we can see the agency of refugees being acted out in various ways (see Jansen 2015). This body of work suggests that the theoretical framing of the refugee as lacking agency needs to be reworked. Political theorists engage in lengthy discussions about which of these solutions is most ethical under the circumstances and how they ought to be achieved, without considering that refugees should themselves have some control, beyond merely a voice, over what is the best solution for them. Excluding refugees from having agency, I argue, involves not only their lack of participation in developing solutions, but also participation in theory itself. They are excluded from being conceived of as active participants in the theoretical discourse which holds them as its object.

However, this reworking is not at all straightforward - indeed, I argue that it has radical implications for political theory itself. Far from being powerless, refugees have the power to completely disrupt our theoretical framework for understanding the international political order of things. The problem that prevents liberal political theory from constituting the refugee as a political agent is that it is often structured around a specific conception of the world order, specifically the nationstate system. While the task of theory is to critique prevailing political and social structures and articulate alternative ethical visions, its structure may limit the positive role it can play here. At one level the problem is the extent to which political theory "accepts and works with certain components of the international refugee framework that should be contested" (Cole 2016: 261; and see Chimni 2009). But 
even where it moves beyond these categories, at a deeper level political theory remains committed to components of the nation-state system with its assumptions of membership and sovereignty. Ana Maria Alonso comments on "the hegemonic role in Western theory of a state-centric perspective on identity and politics ..." (Alonso 1994: 381). Because refugees no longer have effective citizenship of their home state, they effectively have no political agency, and so remain a problem that has to be solved on behalf of those who do have political agency - citizens of nationstates. David Turton observes:

The figure of the refugee exposes a contradiction in the idea of the nationstate, as both a culturally homogeneous political community, and as the universal principle of political organisation. The refugee is 'out of place' in a conceptual as well as an empirical sense. He or she is an anomaly produced by the universalisation of political organisation (Turton 2003: 4). Refugees are, in effect, citizens of nowhere. ${ }^{1}$

An additional challenge is that political theory not only assumes the legitimacy of the nation-state system, it locates itself within that system - it is 'insider' theory, assuming a specific perspective from inside a nation-state. This means that the solutions it develops in answer to refugee questions are limited in scope, with the nation-state as the centre and the refugee at the margin. The refugee is constructed as an aberration, a challenge to the nation-state system, which must be solved on behalf of that system. Political theory therefore has a topology, theorizing from inside a nation-state, with the citizen as the core subject and the refugee as the peripheral object. On top of that, political theory has a topography, theorizing from within a particular kind of nation-state in a particular part of the world: a liberal democratic state in the Global North. Political theory therefore has a landscape, and just as refugees are caught up in a real landscape of borders and barriers that confine them and limit their agency, they are caught up in an equally confining theoretical landscape of concepts and frameworks. The refugee is framed by theory, and so we, as political theorists, need to critically examine the way that framing functions to deny refugees political agency within our theories.

\section{The Issue of Framing}

The issue of 'framing' the refugee became apparent to me when I took part in an event called Exile and Migration, which consisted of the screening of two films about refugees. ${ }^{2}$ The films placed refugees in the camera frame and allowed them to speak directly to the audience, representing themselves. The point of the event was to show that one important challenge we face in talking about refugees is who gets to talk about them and how they are represented in that talk. Debates in politics and the media have a particular frame, and that frame is determined by power relations, including the power of representation: only a limited range of voices is empowered to represent themselves and to represent others in these debates, and refugees' representation is largely determined for them. Others speak for them rather than allowing them to speak for themselves, and in speaking for them construct refugees in specific ways and for specific purposes. The two films broke out of that confinement and were thus radical interventions in the debate - no other voices were heard apart from those of refugees. However, one challenge is still the question of who is holding the camera. We know that representation in film is 
determined by who controls the camera and the editing process, and that what we see in these particular films is still being determined by a particular perspective and from a place of power. The films were not made by refugees, and we have to ask whether the representations would have been different if they were. I do not know the answer to that question, but I do know there is only one way of answering it.

The BBC series Exodus $s^{3}$ was slightly different in that significant parts of it were filmed by refugees through the use of smart phones, but still the editing and the production of the final programmes were not under the control of those refugees. Another example of a refugee-centred film is Midnight Traveller, a feature-length documentary filmed on mobile phones by a refugee family escaping Afghanistan, edited into a documentary by Emelie Mahdavian, a California-based film maker. ${ }^{4}$ All of these represent extremely valuable interventions in the refugee debate, and importantly showcase the refugee voice, as no one other than refugees speaks in them. But it is important to note that there is a process here; as Ilan Kapoor notes in relation to academic studies in the field of international development, "there is no escaping the question of who edits the stories, how they are represented, for whom and what purposes they are framed and so on" (Kapoor 2004: 637). For Kapoor, first-world analysts make themselves invisible in a process of interpretation, and the same "invisibility" is apparent in these documentaries. A final point about the documentaries is that the focus is on refugees trying to reach Europe, and this Eurocentrism features in much of the literature that has appeared on refugees in the past few years. There are obvious - and in many cases excellent - reasons why this should be so, and much of this literature is extremely important. But at the same time, it is worth noting that Europe is, in a sense, the centre of attention. However, rather than this being meant as a deep criticism of these important and valuable documentaries and books, we should perhaps note these two problems of control over the production of representations and the Eurocentrism of the discourse and keep them in mind when we look at political theory.

And so the main subject of my paper is not rights, but power, and specifically the power of representation. I am not going to make some pretty obvious points about how refugees are represented in European media or in political debates. My subject is how refugees are represented in liberal political theory. I think that what emerges from an otherwise very abstract and theoretical discussion is an extremely practical point: the power of self-representation is as crucial for refugees as it is for any other political agency, and the rights we need to be thinking about are the rights that would provide a framework for that power. Liberal political theory - to the extent that it fails to address this question - is as complicit in the framing of refugees as are the media and political leaders. That failure arises, at least in part, from not seeing refugees as political agents at all. And so our question is: why does liberal political theory construct a concept of the refugee that does not contain any element of political agency? We do not deny that in practice refugees are often agents, but would argue that they are not recognised as such in most political theory. Even in practice, while refugees can often be agents, they are still not political agents with the power to represent themselves and to bring about change in the political order.

And so, despite the urgency of the practical issues relating to refugees that we face today, my discussion here is unapologetically theoretical. The fact is that theory becomes more crucial at times of great urgency. Theory enables evaluation and 
critique to take place, because it is at the level of theory that we can imagine alternative possibilities to the current order of things, and ask why that order persists when better possibilities are open to us. In times of political crisis, the use of the imagination is precisely what is required, as Hannah Arendt points out so forcefully. ${ }^{5}$ This means our discussion is not limited by states, citizenship and nations as we find them in the world. Rather, we can explore alternatives as we use theory to imagine different political orders. If some people respond by saying this work is not sufficiently rooted in the real world, we should remind them that the systems of citizenship and exclusion that are actually practised by states are, in an important sense, not part of the real world but are themselves constructs. Current political practices of membership are contingent, perhaps even arbitrary. Most are very recent developments, and so I see no good reason why existing practices should define the limits of our thinking about migration, membership and displacement. We should also remember that political leaders are all too willing to re-write the rules of membership to suit their own agendas, so why should we as theorists not be prepared to re-write those rules in radical ways?

However, while theory's task is to challenge political discourse and practices, it too faces fundamental challenges; and these challenges are what I wish to explore. Theory may have a form - a topology - such that it cannot play a positive role in arriving at an ethical answer to the question of what should be done about refugees and by whom. Its own structure may be at odds with that project. This may sound odd - surely it is through political theory that we build conceptual structures and systems of ideas. But anybody who takes psychology and psychoanalysis seriously is aware that human consciousness does not create ideas in free form, but itself has a structure which constrains what it can create. It is only by reflecting back on itself that consciousness can free itself from those constraints and become truly creative. I am suggesting that political theory - specifically liberal political theory - has a structure that constrains what it can create. Before it can approach the refugee question and offer an ethical vision in response, it must reflect back upon itself and free itself from those constraints. Liberal political theory is in fact itself a practice, and as such has limits which could be, on examination, exposed as contingent and perhaps arbitrary. It is not a space free of contingent limitations upon how we think, and so those limitations must be exposed and critically examined to see if we ought to move beyond them.

\section{Structural Exclusion}

As a framework for thinking about how liberal political theory frames the refugee and why, I want to introduce the contrasting views of global poverty in international development theory, the residual and the relational. The residual view sees the global poor as a leftover - a residue - from the international economic system. This residue is not created by the economic system; instead, the residue contains something that prevents it from being absorbed. Either that residue has to be reformed so that it can be absorbed, or the international system can be tweaked a little so that it can be absorbed as it is. Johnson and Farooki comment: "the poor are seen as a residual category, and need to be integrated better into markets ..." (Johnson and Farooki 2012: 187-8). The residual view of poverty normally accompanies neoliberalism; "as neoliberals might argue, if markets worked better 
and were more efficient, everyone would be included in them in productive ways and would be able to make a living" (Johnson and Farooki 2012: 188).

The relational view sees the global poor as a product of the relationships between people in the international economic order: some people are poor because others are rich (Johnson and Farooki 2012: 188). This relational view is connected with structuralist (Marxist) approaches to international development, as it is the structure of the international economic order that creates the relationships determining who is poor and who is rich. That order produces an inside and an outside, and indeed depends on it; the "order" of the economic order depends on the active exclusion of the global poor. More accurately, the global poor are inside the economic order but confined to its margins in a space where political agency is absent. They are on the outside in the sense that they are excluded from processes of power, but remain an essential part of that order as it cannot be maintained without their participation. Rather than exclusion, we may want to talk about oppression and exploitation here. The crucial point is that the global rich and the global poor are in a relationship with each other - they constitute each other, such that solutions to global poverty have radical implications for the position of the global rich. The solution to global poverty from this structural perspective is the overthrow of the economic order. This residual/structural contrast can be applied to many issues of exclusion - political and social as well as economic - such as the position of women, ethnic minorities and the physically disabled. These groups may lie outside the political or social order because of factors inherent to them, or because of a minor inefficiency in that order that could be tweaked so they are included, or that order structures itself around the oppression and exploitation of certain others who must be excluded from political agency. The refugee can also be seen this way. Refugees are a residual leftover outside the international system of sovereign nation states, but their exclusion has nothing to do with that system or is due to some minor problem that can be tweaked. Or they represent a structural failure, caught up in relations of oppression and exploitation such that finding an answer means asking radical questions about the international political order itself, including the position of those who are not refugees.

However, my focus in this paper is on how the idea of the refugee is produced and how political theory constructs an inside and an outside. My main contention is that the residual/structural approaches can be employed at the level of political theory itself. What we should notice is that certain groups are not only excluded from economic, political and social systems, but are also excluded from theoretical systems. Of course, this is not news - theorists have long been aware of these exclusions and many have addressed them. ${ }^{6}$ But the key point is to notice that we can understand these exclusions as either residual or structural. If the exclusion is residual, all we need to do is tweak our theory a bit to include refugees and then carry on more or less as before. If exclusion is structural, then we have to recognise that the excluded are actually present in political theory, because the order of that theory construct depends on maintaining relations of oppression and exploitation. Their presence, though, is implicit - they are excluded at the level of theory by being made invisible despite being structurally present. This means we need to radically rethink our political theory in order for it to be genuinely inclusive - we cannot go on as before. I contend that this exclusion is structural: the inside and the outside are produced by the theory itself, and business as usual is not an option. 
Theory, like media and political discourse, has a shape, a topology. Historically, those considered "other" were simply excluded from liberal political theory altogether, although they have always been structurally present. More recently, where it has begun to acknowledge the existence of various "others", it has structured their exclusion as a problem that has to be solved in the interest of the already-included - those who are already political agents. Their presence within theory becomes deeply disruptive and disturbing for that core political agency, because it has been structured through oppression and exploitation against the "outside". In order for business to proceed as usual, any "inclusion" has to be incomplete and compromised. Even though they are now on the "inside", the "outsiders" remain outsiders, marginalised, voiceless and powerless, as the figure that has traditionally been at the centre of the theory holds on to its power. Again, this power of political agency is the power to change the theoretical structure in such a way that those at the centre remain there. This exposes theory as deeply flawed and in need of radical critique. Rather than a tweak here and there and business as usual, we may have to start from scratch.

\section{At the Margins of Theory}

I propose that this is how we should see the concept of the refugee in liberal political theory. That theory has notoriously been structured on the assumption that we are dealing of members of a specific nation state. This is an assumption I have confronted in my work on international migration, arguing that the migrant should figure equally with the citizen in any ethical discussion of immigration, rather than only the citizen's interests dominating the theoretical discussion. International political theory, when it does address the ethics of migration, is equally structured on the assumption that people, even if they are migrants, are members of another nation-state which they have left voluntarily - they have not been forcibly displaced. We have confronted the fact that the migrant was not included as a political agent within liberal political theory, and we now need to recognise that the refugee has not been included as a political agent within international political theory, however cosmopolitan we believe that theory to be.

The obvious reply to this critique is that we are addressing the migrant and the refugee in liberal political theory, otherwise we would not be here now discussing them. However, my argument is that we cannot simply apply the political theory we have to the problem of the globally displaced, because the existing political theory does not acknowledge migrants' and refugees' existence as political agents. Even though the migrant is now included in much liberal political theory, so far as I'm aware they are not granted the power to negotiate political change. They are therefore included in that theory as a specific kind of problem that keeps them at the margins of theory, not allowing them to become the central question or agency of theory. This marginalisation must be maintained because if the displaced were to become the central question of theory, they would expose that theory as fundamentally incoherent and structurally flawed. If marginalised individuals become the agents of theory then everything may change in radical ways - and then we come back to the issue of who holds the camera.

When Philosophies of Exclusion (Cole 2000) was written, the major aim of the argument was not, in fact, to justify open borders, but to show that addressing the 
question of membership has the power to undermine the entire coherence of liberal political theory. Immigration is not some marginal question which we can add on to theory, but rather goes to the heart of that theory and exposes it as flawed. The conclusion drawn in that book was that liberal theory had a choice, either to embrace open borders or to embrace its own incoherence, and many theorists have indeed embraced that incoherence and tried to make sense of it rather than accept the open-borders implications of their theory. Whether they have succeeded or not is a matter for their readers. The Refugee Question shows that the structural flaws go much deeper than was accounted for in Philosophies of Exclusion. The problem we face is that liberal political theory has been an "insider" theory, a body of theory that privileges the voice of the insider, the one who possesses statehood, the citizen. That privilege at the extreme has resulted in this being the only position acknowledged as existing. But even where we recognise the existence of the displaced as a problem for political theory, they are included as a problem for the citizen, a problem that has to be solved in the interests of the citizen. Any solution to that problem has to keep the interests of the citizen at the centre. This is done by reserving the power of political agency for the citizen. Displaced persons, although now included as an object of theory, are not a subject - they have no agency.

I contend that the problem is even worse than this. Not only has liberal theory been "insider theory" with a specific topology, theorising from inside a nation-state (and that is a generous reading of its scope), it has also had a specific topography, theorising from inside a particular kind of nation-state in a particular area of the world. Liberal theory has a geographical shape, as a body of theory structuring a viewpoint on migration and membership centred upon the interests of those who already have membership of a particular kind of nation-state in a particular location in the world. This means that any answer to the refugee question produced by this theory will be structured around the interests of those specific members. And so the relationship we are trying to understand here is not simply between refugees and citizens, but between refugees and citizens of liberal democratic states in the Global North.

As I have already indicated, that relationship is distorted by power relationships both in theory as well as in practice. I argue that we need to acknowledge not only theoretical but also psychological tension here, and indeed that these two are connected. Imogen Tyler has written about "revolting subjects", using the core concept of abjection (Tyler 2013). Tyler draws on the work of George Bataille (Bataille 1993 [1934]), who argues that "abjection is the imperative force of sovereignty, a founding exclusion which constitutes part of the population as moral outcasts: 'represented from the outside with disgust as the dregs of the people ..."' (Tyler 2013: 19; internal quotation from Bataille 1993 [1934]: 9). “These surplus populations are disenfranchised to the degree that they are 'disinherited [from] the possibility of being human'" (Tyler 2013: 19; internal quotation from Bataille 1993 [1934]: 11). The "abject" is precisely that revolting residue we saw in the neo-liberal approach to the global poor. Barbara Creed writes that the sources of the abject are those things that disrupt the boundary between the living body and its own death, such as bodily wastes and decay. These are things that threaten our identity as a member of humanity, such that we wish to expel them behind a border which will protect us from them. However they are part of who we are, so that expulsion needs to be constant, and the border is constantly threatened. Because of this constant 
need to repel, ritual becomes centrally important to maintain the boundary between the human and the non-human, and that ritual has to become more detailed, complex and intense. Creed says that the abject has to be radically excluded and "deposited on the other side of an imaginary border which separates the self from that which threatens the self" (Creed 1993: 9). ${ }^{7}$

Much more could be said about the abject and Tyler's use of it, but for now I want to point to the small conceptual leap in applying this to the politics of migration and membership as boats filled with desperate humanity crossing the Mediterranean and other seas are constructed as abject and to be repelled, for some at all costs. These migrants have been likened recently in the United Kingdom to cockroaches (see Williams 2015), and those who were gathered at Calais in France were described by the UK Prime Minister at the time as a "swarm" of migrants threatening to overwhelm his country (BBC 2015). We saw this framing played out during the Brexit campaign, with Nigel Farage's now infamous poster, and newspaper headlines playing on similar imagery and fears.

This tension is evident at the level of theory as well as in practice. The visible presence of the "other" in political theory - that against which the core identity is defined - is theoretically disturbing and disruptive; it is revolting. First, the visible presence of the "other" reveals that the core identity is not universal but is particular - it exposes what Vron Ware and Lee Back describe as the "unwitting" solipsism of the "individual unaccustomed to questioning the idea that she or he occupies a privileged political and cultural category" (Ware and Back 2002: 5). Second, it reveals that the core identity is not some solid, pre-theoretical given around which everything revolves, but a theoretical construct which can be deconstructed and displaced. Third, it reveals that this core identity depends on maintaining a power relationship with the other, but one filled with tensions and antagonisms that cannot be resolved without a radical revision of the entire theoretical landscape. And so the problem of the other must be "solved" but in a way that keeps it tightly controlled and confined, so that the position of the core identity is maintained. This relationship then becomes ever more tense, antagonistic and often violent, so that these so-called "solutions" to the problem only make it worse.

\section{Challenging Topographic Enclosure}

Any solution to the refugee question constructed within liberal political theory even in its international form - thus cannot be genuinely inclusive and egalitarian, because the negotiation on which that solution is based cannot take place on an equal basis. Indeed, any negotiation will likely only take place between those recognised as political agents, with refugees positioned as outsiders. Theory is based on a core and a periphery, with the core structured around the insider and the "other" - in this case the refugee - confined to the periphery. Refugees must be confined, because as we saw earlier, bringing them to the centre shows the theory to be deeply flawed and shows the subject - the citizen/member - at the centre of theory, whose interests it prioritises, as equally deeply structurally flawed. The integrity of the subjects depends on the exclusion of the "other", and their continuing position, identity, interests and power still depend on confining the "other" to the periphery, even if we acknowledge their existence. 
The topography of theory - the fact that we are talking about the relationship between refugees and citizens of liberal democratic states in the Global North - also allows us to acknowledge the role of history in shaping this relationship. International constraints on freedom of movement, as Chandran Kukuthas points out, function mainly to prevent movement of the global poor (Kukathas 2005: 213), ${ }^{8}$ and this directive shapes a great deal of political rhetoric and policy around refugees. At the level of liberal theory, we typically find that much of the detail is abstracted out in discussions of migration, membership and refugees. We end up discussing an idealised liberal state and its relationships with undefined outsiders, with little acknowledgement of the role of the global political system and of history. The reality is that we are not - or should not be - discussing the rights of a particular liberal state to control its borders in an idealized sense. We are talking about a global migration regime, through which a block of powerful liberal capitalist states seek to control migration flows for their own purposes. What we face is the unjust relationship between the political "inside" (the Global North) and the political "outside" (the Global South) which has been sedimented through the historical processes of colonialism and post-colonialism. This gives us another reply to those critics who charge political theorists with being idealistic and unrealistic. It is actually the more "traditional" liberal approaches to this issue that are idealized, with a refusal to acknowledge the power relations that structure these issues around colonial and neo-colonial relationships of oppression, exploitation and exclusion.

The challenge facing theorists is how to break out of this topographic enclosure in a way that does not assume some neutral theoretical space that theorists can occupy to move directly to an answer on the refugee question. Rather, our priority has to be to contribute to building a genuinely inclusive theoretical context within which all have equal voices in reaching an egalitarian settlement based on universal principles of justice. In other words, our first task is not to find the right answer to the question, but to find the right way of answering it. This approach is based on the realisation that everything has to be up for negotiation - there can be no fixed points, because what we take to be fixed points have been fixed by the old topology/topography of theory, and those fixed points are the problem. To think that we can arrive at a solution to displacement based on those fixed points is the mistake. We have to start from scratch. This requires rethinking not only the concept of refugees and their rights, but also the concept of citizens and their rights. We cannot rethink the meaning of the idea of the refugee without rethinking the meaning of the idea of the citizen, because the inside is defined by the outside and depends upon it. To revise the conception of the outside is to radically threaten the inside. The fact is that the rights of the person who is already safe are what restrict the rights of those who seek safety. And this, of course, means that the very idea of the liberal nation-state is also thrown into question. This power to disrupt the theoretical landscape so completely is what makes the refugee so revolting.

The theoretical basis for discussions of membership and mobility must be challenged. What membership means and the rights that attach to it have to be fought over, rather than taken as our starting point. The fight is not just for membership, but also for its meaning. And we must recognise that the meaning of membership will be determined not by theorists and policy makers, but by those who seek it, who act out these ideas in their everyday lives. What is needed is a dialectic between theory and lived experience. This is always how moral and 
political concepts have been determined - not through abstract thought, but through political and practical struggle, and through ordinary people seeking to improve their lives and the lives of those around them in conditions of oppression. Political theory must become cosmopolitan in the true sense of the word, by providing space for all these voices and experiences, by embracing our common humanity in all its variety and dissolving the boundaries that separate "us" from "them".

These thoughts imply that political theorists are not best placed to offer an ethical answer to the refugee question. Instead, we should focus on the prerequisite task of constructing an ethical framework within which the question can be answered. Even then, that framework, in addition to recognising the equality of the position of the refugee alongside other political positions that constitute it, must also recognise the equality of the refugee voice in the process of shaping the ethical framework. In other words, it is not good enough for political theorists to construct an ethical framework for answering the refugee question that recognises the role of the political agency of refugees in arriving at an answer; we must also recognise the role of the agency of refugees at the level of theory. Again, the question is who is holding the camera. And so it may be that the most important right for refugees is not the right to safe passage nor to make a new home in a place of safety, but the right to self-representation at all levels of political debate, including, crucially, political theory itself.

The way in which the privileging of the voice of the insider is deeply ingrained within political theory is shown by Seyla Benhabib's use of discourse ethics to establish a human right to membership. Her discourse between the insider and the outsider goes as follows (note that from the beginning she, as the speaker, is the insider):

If you and I enter into a moral dialogue with one another, and if I am a member of a state of which you are seeking membership and you are not, then I must be able to show you with good grounds, grounds that would be acceptable to each of us equally, why you can never join our association and become one of us. These must be grounds that you would accept if you were in my situation and I were in yours. Our reasons must be reciprocally acceptable; they must apply to us equally (Benhabib, 2004: 138).

In order to be acceptable, such grounds would be related to qualifications, skills and resources (Benhabib, 2004: 139). But note that the crucial aspect of the discourse is that these must be grounds that you would accept if you were in my situation. In other words, the outsider must think from the perspective of the insider, and so once more the perspective of the insider is privileged. The sentence should at least read: These must be grounds that you would accept if you were in my situation and I would accept if I were in yours. As it stands, there is no reciprocity here. If the grounds for exclusion are to be genuinely "acceptable to us equally", then they have to be acceptable to the outsider as outsider. And equally importantly, they must be contested against grounds for inclusion which must carry equal weight in the exchange. This means that the grounds might be much wider, and perhaps completely different, from the ones Benhabib identifies as qualifications, skills and resources, as these seem to reduce the outsider - the migrant or refugee - to an economic calculation.

Lori Watson points out: 
The emphasis on reasons we could not reasonably reject as the standard of moral justification requires us to recognize that such reasons have the character they do, in part, because they are reasons we can share - as moral equals. Acknowledging that immigrants stand in a political relationship visà-vis the state of intended migration requires acknowledging that the state is obligated to offer justifications that could not be reasonably rejected for its principles. This, however, also requires acknowledging the immigrant as a reason-giver in this context, and as an equal (Watson, 2008: 988).

But in order for the migrant or, for the purposes of our discussion, the refugee, to be an equal in this exchange, we must be able to give our reasons from positions of equality. To make this possible we have to be prepared to think outside of the conventional political frameworks that position the refugee as the "problem" figure in this relationship. It is not the refugee who is the problem, but the relationship itself, a relationship which privileges the reasons of the "insider" and renders the "outsider", in this case the refugee, silent.

To relegate the rights to safe passage and sanctuary to the level of second-order rights may seem paradoxical, but it points to the fundamental injustice here, the objectification of refugees as passive burdens dependent on the benevolence of Global North nation-states. We have to overcome that objectification together, so that the refugee becomes the active agency in answering the refugee question. Indeed, this may change the question fundamentally so that the focus moves away from what the rights of the refugee should be to the rights and duties of the citizen of the liberal nation-state. In other words, the refugee question was never the right question to begin with. The right question was always much bigger and much more challenging for those citizens - because we realise that if we ask the right question, it is not the refugee who is the problem, we are. Unless we as citizens of such states are willing to problematize our own power, our own safety and security, we have to accept that we are not willing to take the refugee question seriously. And that includes the power to make theory. ${ }^{9}$

\section{Back to the Democratic Puzzle}

At the start of this paper I formulated what I took to be the key research question: why does liberal political theory construct a concept of the refugee that does not contain any element of political agency? The follow up question is: how do we as political theorists construct a concept of the refugee that includes political agency, such that refugees have the power to negotiate an answer to the mainstream version of the question: what should we as an international community do about refugees? That, as I admitted at the start, is a very abstract question, and part of the answer that the shaping of the concept of the refugee has to be informed by those who are to be framed by it - is equally abstract. But I also suggested that this discussion takes us to a very practical outcome: that the power of self-representation is as crucial for refugees as it is for any other political agency, and that the rights we need to be thinking about are the rights that would provide a framework for that power.

This brings us to the very practical question of representation. At the time of writing, the Office of the High Commissioner for Refugees (UNHCR) estimates that there are 79.5 million forcibly displaced people throughout the world (https://www.unhcr.org/uk/figures-at-a-glance.html: accessed November 16, 
2020), a number greater than the population of the United Kingdom. The 26 million refugees would make a nation larger than many existing nation-states who have a seat at the United Nations and other bodies that decide their fate. And if we expand the notion of the refugee as anyone who is forced to leave their home, without worrying about what or who does the forcing and where they are forced to go to, the number is even larger. This massive body of people clearly need to represent themselves so that they have political agency. But how is this to be operationalised?

I said before that refugees do have agency, a fact that bothers many Global North states. They exercise agency by travelling to their preferred destination. All the legislation in the European Union, such as the Dublin III regulations and the agreements negotiated by the EU with Turkey and African states, is aimed to deprive them of even this agency. The preference is that refugees exercise the minimal agency required to get them over a border (just not a Global North border) and into a refugee camp so that they can be resettled through the UNHCR or some other programme, despite the fact that there are too few resettlement places for those who need them. We also see other examples of refugee and asylum seeker agency. "You can't evict a movement" was one of the slogans used by the asylum seekers who set up an illegal camp in Oranienplatz in Berlin in 2012. The protestors came up with a programme of demands for reform around the idea of human rights, a rare example of the voices of asylum seekers and refugees entering the debate. Those voices were silenced when the authorities bulldozed the camp in 2014. In his paper (Benli 2018), Ali Emre Benli examines the march of asylum seekers stranded in Budapest's Keleti train station to the Austrian border in September 2015, in an attempt to reach Germany and Sweden. That had a happier outcome as the Hungarian authorities sent buses to transport them to Austria. But despite that success, all political developments in Europe and elsewhere aim to narrow the scope for asylum seekers to exercise agency, and political agency - the power to negotiate change in the political order - is simply not on offer.

Some proposals have been made, but they have been controversial, such as the idea of the Refugee Nation put forward by real estate millionaire Jason Buzi, and the proposal to establish a nation-state for refugees with its own territory (also see Cohen and Van Hear (2017) on their proposal for Refugia). ${ }^{10}$ Alexander Betts argues that Buzi's idea as it stands has a lot of problems, but he sees value in the idea of the Refugee Nation if it recognises the capacities of refugees to build representative political structures. Betts points out that Buzi's territorial concept leads to exclusion rather than inclusion, and that we should instead understand the Refugee Nation as a representative concept, so that refugees have an equal voice at the centre of discussions about their rights and the responsibilities of the international community (see Betts 2015). In other words, the Refugee Nation would be a representative body with seats at the table at the key agencies where the refugee question is discussed. We must ensure that the refugee voice is heard within global civil society as an equal member and partner in reaching equitable answers to the refugee question.

Two responses have come up when I mention the idea of the Refugee Nation. The first has been to raise the problem of how the Refugee Nation becomes represented. As soon as we identify a body of people who need to be represented, divisions open up within that body, and finding a way of representing all of the 
different positions becomes impossible. In attempting to represent the refugee body, we homogenize it in ways that are very damaging. Given that no agreement exists about who counts as a refugee, we are not going to get agreement about who represents the refugee. However, this problem arises for any issue of representation in democratic politics, and yet we still manage to democratize many political issues. The democratic puzzle of how a body of people gets represented should not be the exclusive property of those who are already citizens. Otherwise, it starts to look like a privilege rather than a problem. And so while I do not have an answer to that challenge, my response is that we will work it out somehow, as we have managed to work it out in the everyday life of liberal democracies. The second response is to ask where the Refugee Nation should be represented - on what international bodies? Again I don't have an answer to that question. This is precisely the kind of issue which needs to be worked out through inclusive negotiation. There is a fundamental point here about the humility of theory - it is not for me as a political theorist to decide; there are far better ways of working these things out.

This does however bring us back to the democratic puzzle. I said earlier that the most important role for political theorists is to focus on the prerequisite task of constructing an ethical framework within which the refugee question can be answered rather than to arrive at an answer to the question, and that this framework must be one that recognises the equality of not only the position of the refugee alongside other political positions that constitute it, but also the refugee voice in the process of deciding what the ethical framework should look like. The same challenge exists at the practical level - we need a political framework that recognises the position of the refugee in negotiating political solutions to the refugee question, but must also recognise the position of the refugee in negotiating what the political framework looks like. In order to arrive at a framework that embodies the political agency of refugees, we must recognise the political agency of refugees at the outset. This is a pretty standard problem in the process of establishing democratic politics, and we have managed to work it out before. There is no reason I can see why we should suddenly lose our democratic optimism on this question, unless we really are unwilling to problematize our own power.

\section{Acknowledgment}

This paper was written with the support of a Senior British Academy Research Fellowship, the Thank-Offering to Britain Fellowship. I would also like to thank the anonymous referees and the journal editors for their comments and suggestions, which have led to a much-improved final version of the paper.

\section{Notes}

${ }^{1}$ A more radical form of being a citizen of nowhere is, of course, to be stateless, which the majority of refugees are not. On statelessness specifically see Cole 2017. My point here is that refugees lack an effective citizenship as they have been forcibly removed or have fled from their home state, and, in the absence of the durable solution of integration, do not have effective citizenship of their host state. 
${ }^{2}$ Exile and Migration took place at the Trinity Centre in Bristol - see details of the films here: https://www.3ca.org.uk/whats-on/2017-archive/exile-and-migration. The films here "Leaving Greece," directed by Anna Brass, and "Boya Boya" directed by Karen Boswall and Ruba Al Akash.

${ }^{3}$ https://www.bbc.co.uk/programmes/b07ky6ft

${ }^{4}$ For media coverage see Horton (2019).

5 "Imagination alone enables us to see things in their proper perspective, to put that which is too close at a certain distance so that we can see and understand it without bias and prejudice, to bridge abysses of remoteness until we can see and understand everything that is too far away from us as though it were our own affair" (Arendt 1953: 392). "Without this kind of imagination, which is actually understanding, we would never be able to take our bearings in the world. It is the only inner compass we have..." (Arendt 1953: 392).

${ }^{6}$ Here I have in mind work in the different fields of feminist, postcolonial and disability theory, for example. For a recent discussion of the first of these, see Goldenberg (2007); for the second, see Spivak (1998); and for the third, see Arneil and Hirschmann (2017).

${ }^{7}$ See also Cole (2006: 113-117).

${ }^{8}$ It is interesting to note how the Poor Laws in England during the $17^{\text {th }}$ century sought to control migration of the poor. The Act "for the better reliefe of the poor" passed in 1662 was "principally concerned with restricting migration, and providing the basis for the exclusion of outsiders from a given parish."

${ }^{9} \mathrm{Up}$ to this point in the paper, when I have referred to 'we', I have meant we as political theorists. In this paragraph I move between three senses of 'we': firstly, we as political theorists; secondly, we as citizens of Global North states; and thirdly, we as members of humanity. I assume the reader can tell which of these I am referring to at various places in the paragraph.

${ }^{10}$ See http://www.refugeenation.org/news.html

\section{References}

Alonso, A. M. (1994). “The politics of space, time and substance: State formation, nationalism and ethnicity", Annual Review of Anthropology 24: 379-405. https://doi.org/10.1146/annurev.an.23.100194.002115

Arneil, B. and N. J. Hirschmann eds. (2017). Disability and Political Theory. Cambridge: Cambridge University Press. https://doi.org/10.1017/ 9781316694053

Arendt, H. (1953), “Understanding Politics”, Partisan Review, 20 (4): 377-92.

BBC (2015, July 30). David Cameron criticised over migrant 'swam' language. BBC. Retrieved February 22, 2020, from http://www.bbc.co.uk/news/uk-politics33716501

Benhabib, S. (2004). The Rights of Others. Cambridge: Cambridge University Press. https://doi.org/10.1017/CBO9780511790799

Benli, A. E. (2018). March of refugees: an act of civil disobedience. Journal of Global Ethics 14/3: 315-331. https://doi.org/10.1080/17449626.2018.1502204

Betts, A. (2015, August 4). Is creating a new nation for the world's refugees a good idea? The Guardian. Retrieved February 22, 2020, from 
http://www.theguardian.com/global-development-professionalsnetwork/2015/aug/04/refugee-nation-migration-jason-buzi

Chimni, B. S. (2009). “The birth of a 'discipline': From Refugee to Forced Migration Studies”, Journal of Refugee Studies 22(1): 11-29. https://doi.org/10.1093/ jrs/fen051

Cohen, R. and N. Van Hear (2017). "Visions of Refuge: Territorial and transnational solutions to mass displacement." Planning Theory and Practice 18 (3): 494-504. https://doi.org/10.1080/14649357.2017.1330233

Cole, P. (2000). Philosophies of Exclusion: Liberal Political Theory and Immigration. Edinburgh, Edinburgh University Press.

Cole, P. (2006). The Myth of Evil. Edinburgh, Edinburgh University Press. https://doi.org/10.3366/edinburgh/9780748622009.001.0001

Cole, P. (2016). "Global displacement and the topography of theory", Journal of Global Ethics 12 (3): 260-8. https://doi.org/10.1080/17449626.2016.1247745

Cole, P. (2017). Insider theory and the construction of statelessness." In T. Bloom, K. Tonkiss and P. Cole eds. Understanding Statelessness. London and New York: Routledge. https://doi.org/10.4324/9781315200460-19

Creed, B. (1993). The Monstrous-Feminine: Film, Feminism, Psychoanalysis. London, Routledge.

Goldenberg, M.J. (2007). "The problem of exclusion in Feminist Theory and Politics: A metaphysical investigation into constructing a category of 'woman'," Journal of Gender Studies 16 (2): 139-153. https://doi.org/10.1080/09589230701324603

Horton, A. (2019, September 25). Midnight Traveler: a powerful refugee documentary filmed on a phone. The Guardian. Retrieved February 22, 2020, from https://www.theguardian.com/film/2019/sep/24/midnight-travelerrefugee-documentary-afghanistan

Jansen, B. J. (2015). “'Digging aid': The camp as an option in East and the Horn of Africa," Journal of Refugee Studies. 29 (2): 149-165. https://doi.org/10.1093/jrs/fev018

Johnson, H. and M. Farooki (2012). “Thinking about poverty," in . T. Pappioannou and M. Butcher eds., International Development in a Changing World. London: Bloomsbury.

Kapoor, I. (2004). Hyper-self-reflexive development? Spivak on representing the Third World 'Other'. Third World Quarterly 25(4): 627-647. https://doi.org/10.1080/01436590410001678898

King, N. (2016). No Borders: The Politics of Immigration Control and Resistance. London: Zed Books.

Kukathas, C. (2005). The Case for Open Immigration. In Cohen, I. and Wellman, C. H. (eds.), Contemporary Debates in Applied Ethics (pp. 207-220). Oxford: Blackwell Publishing.

Lenard, P.T. (2020), "Refugees as (political agents): A review of three recent books in the political theory of refugees." Res Publica. 26: 451-9. https://doi.org/10.1007/s11158-020-09449-1

Spivak, C. G. (1998). In other worlds: Essays in Cultural Politics. New York: Routledge.

Turton, D. (2008). "Refugees, forced resettlers, and 'other forced migrants': towards a unitary study of forced migration," New Issues in Refugee Research 
Working Paper No. 94, UNHCR Evaluation and Policy Analysis Unit, September 2003.

Tyler, I. (2013). Revolting Subjects: Social Abjection and Resistance in Neoliberal Britain. London, Zed Books.

Ware, V. and Back, L. (2002). Out of Whiteness: Color, Politics, and Culture. Chicago, University of Chicago Press.

Watson, I. (2008). "Equal justice: Vomment on Michael Blake's immigration and political equality.” San Diego Law Review. 45 (4): 981-988.

Williams, Z. (2015, April 19). Katie Hopkins calling migrants vermin recalls the darkest events of history. The Guardian. Retrieved February 22, 2020, from https://www.theguardian.com/commentisfree/2015/apr/19/katie-hopkinsmigrants-vermin-darkest-history-drownings 